\title{
Taymyr Reindeer Herding as a Branch of the Economy and a Fundamental Social Identification Practice for Indigenous Peoples of the Siberian Arctic
}

Yulia S. Zamarayeva

Anastasiya V. Kistova

Natalia N. Pimenova

Kseniya V. Reznikova

Natalia N. Seredkina

Siberian Federal University, Russian Federation

Email:k-reznikova@inbox.ru

\section{Doi:10.5901/mjss.2015.v6n3s5p225}

\section{Abstract}

There are two factors affecting the way that Nenets and Dolgan people of Taymyr define their regional identity: 1) their traditional trade (reindeer herding); 2) ethnic art-making where the reindeer acts as an image and a symbol of ethnic traditions, touchstones, and values found among the indigenous peoples of Taymyr. Field research was conducted in Taymyr settlements (such as Nosok, Karaul, and Khatanga) from 2010 to 2014. The researchers interviewed Nenets and Dolgan people who belong to non-governmental organizations representing Taymyr indigenous peoples, run businesses or work in government agencies, schools, and other organizations implementing cultural policies. Indigenous peoples have very low economic and social activity. The Dolgans also have a very poor standard of living due to lack of reindeer. The Post-Soviet era has seen an income gap growing between the Dolgans and the Nenets and unequal economic groups being formed. Reviving reindeer herding is essential. Nenets and Dolgan reindeer herding is an economically inefficient subsidized branch of agriculture, but its role is symbolic rather than economic. Nenets and Dolgan reindeer herding is an ethnicity-forming and ethnicity-sustaining factor. Today's reindustrialization of Taymyr may end up exterminating its indigenous peoples' unique economic, environmental, and cultural practices. Taymyr's political establishment must pay due attention to the threat of ruining these unique practices.

Keywords: reindeer herding, Northern region, regional identity, ethnic identity, Taymyr, Dolgans, Nenets

\section{Introduction}

Taymyr's regional identity is tied with Northern and Siberian indigenous peoples' traditional trade (Kim \& Berry, 1993). Nowadays, Taymyr is a reindustrialization area. Its population includes indigenous peoples, Russian long-term residents, migrant workers, and other ethnic and cultural groups (Karlova et al., 2013). Of special importance to the area are Northern indigenous peoples' traditional trade and traditional environmental and cultural practices (Koptseva \& Kirko, 2014c; Pimenova, 2015; Reznikova, 2013; Syroechkovskiĭ, 1995). There are four indigenous ethnic groups living on the Taymyr Peninsula: the Nenets, the Dolgans, the Nganasans, and the Enets. For centuries, reindeer herding and, to a lesser extent, hunting and fishing have remained these ethnic groups' main traditional economic activities. But during the Soviet and Post-Soviet era, the Nganasans and the Enets lost all of their reindeer herding industry and were unable to rebuild it. Only the Nenets and the Dolgans of Taymyr still practice reindeer herding (Krupnik, 2000; Laruelle, 2013).

\section{Literature Review}

Today's Northern and indigenous research treats reindeer herding as a fundamental economic and cultural mechanism for sustaining Northern indigenous peoples' regional and ethnic identities. These days researchers' attention is drawn to the changes in traditional reindeer herding brought about by globalization and urbanization (Alia, 2010; Wheeler, 2011; Helle, 2013; Bostedt \& Lundgren; 2010, Pape \& Löffler 2012; Næsset al. 2011; Koptseva, 2014, Koptseva \& Kirko, 2014a; Ziker, 2014). Two major approaches can be identified in existing studies. The first approach views reindeer 
herding as a type of traditional husbandry (Chard, 1963; Klein \& Kuzyakin, 1982). The second approach treats reindeer herding as a symbolic foundation for Northern peoples' regional and cultural identification (Luzan, 2014; Seredkina, 2014; Sitnikova, 2015).

\subsection{Reindeer herding and its role for indigenous Northern peoples of Taymyr}

Taymyr reindeer herding is the foundation on which indigenous peoples grow their economic and cultural practices (Krivonogov, 2013; Makarov, 2013; Batashev, 2013; Koptseva, 2014). Indigenous research today pays special attention to the extreme weather conditions in the North and the Arctic affecting indigenous peoples' health and lifestyle (Newcity, 2009; Laruelle, 2013; Klokov, 2011; Koptseva, 2014; Krivonogov, 2013). Most researchers believe that in this day and age reindeer husbandry is unprofitable and uncharacteristic of an industrial market society. Yet there is a need for reindeer herding as the key economic and cultural practice enabling the indigenous peoples of Taymyr to sustain their cultural identities (Syrovatsky \& Vinokurov; 2012, Koptseva \& Kirko 2014b; Pimenova, 2015; Libakova et al., 2014). Traditional economic activity, that is, reindeer herding, is a foundation for social stratification among the indigenous peoples living in Taymyr these days (Williams and Heard, 1986).

\subsection{Reindeer herding as a symbolic foundation for Taymyr indigenous peoples' cultural identification}

Field-based studies by V. Krivonogov (2013) established the key role of the reindeer image in creating an ethnic group's cultural core (with Dolgan and Nenets peoples used as examples). Up until the second half of the 20th century, indigenous peoples' regional identity remained linked to their ethnic identity. Ethnic identity was seen as belonging to a certain bloodline (clan) or a shamanic cult and having a native language (Phinney, 1989). Nowadays, ethnic identity is shaped by an absolutely different range of cultural practices. Indigenous peoples claim their signs, imagery, and symbols that find their way into decorative arts and ethnic paintings, sculptures, videos, and animated films (Seredkina, 2014). The reindeer is a crucial sign, image, and symbol used in ethnic art. There are not many detailed up-to-date studies looking into the reindeer image to analyze Taymyr indigenous peoples' regional identification (Bakhova et al., 2012). In the context of the Experience Economy and ongoing regionalization, indigenous art and craft-making are seen as a new ethnic self-identification practice (Ehrich et al., 2015). Indigenous ethnic groups are able to differentiate between each other by looking at the ornaments, signs, and techniques used in their artwork.

\section{Research Methodology}

Today's methodology applied in indigenous research must help decolonize the indigenous peoples of the North (Tichotsky, 2014; Steinhauer, 2002; Rowe et al., 2015). From 2010 to 2014, scientists from the Siberian Federal University have conducted field research in the Taymyr settlements of Nosok, Karaul, and Khatanga populated by the Dolgans, the Nenets, and the Nganasans. The key methods involved in the research were interviewing, surveying, collecting visual materials, and recording statistical data. The researchers actively sought to gather data from Taymyr indigenous dwellers who work in local government agencies, run a business in Taymyr or work in indigenous peoples' rights protection (as part of non-governmental organizations), schools and other organizations implementing regional cultural policies. Modern-day regional and ethnic identification practices were analyzed by studying ethnic visual arts.

\section{Findings and Discussion}

Being a distinct branch of agriculture, reindeer herding requires a special management approach. It cannot be treated like just any other branch of husbandry, ignoring its unique features and failing to involve reindeer herders themselves in the process. Reindeer herding is practiced purely by small communities who, following the centuries of "popular selection", managed to create the right breeds of Northern domesticated reindeer for the tough local climate and terrain. Four reindeer breeds were recognized in 1985 by Order 212 by the USSR Minister of Agriculture dated August 23rd, 1985: Nenets, Chukotka, Evenk, and Even; in 1993 these breeds were listed in the State Register of Approved Selective Achievements. Nowadays, 540 herder families from 8 reindeer farms are involved in reindeer husbandry in Krasnoyarsk Krai; another 23 families work in the private sector.

Tundra reindeer herding occurs in the Taymyr Dolgano-Nenets Municipal District, which is home to most reindeer herders. Data from the local authorities suggests that as of $1^{\text {st }}$ of January 2014 the area had 95,379 reindeer. Most of them, 86,190 reindeer, were herded by Nenets people in the western end of the area, on the left bank of the Yenisei. 
Reindeer herding in central Taymyr Dolgano-Nenets Municipal District is in decline, whereas Nganasan reindeer herding has disappeared altogether as a type of husbandry. Dolgan people living on the right bank of the Khatanga River still keep 6,752 reindeer.

Tundra forest reindeer herding is practiced in the Turukhansky Municipal District where 797 reindeer still remain.

Forest (taiga) reindeer herding is practiced in the Evenk Municipal District where the Surdinskoye husbandry farm breeds Evenk reindeer. As of January 1st, 2014 the farm had 2,823 reindeer, which is 1,178 reindeer fewer than in 2013.

In 2013 state-owned reindeer farms and private herders in Krasnoyarsk Krai received 59,121,600 rubles in subsidies to compensate part of the expenses on increasing and sustaining their reindeer livestock. Out of this sum, $50,989,600$ rubles were provided by the local government and 8,132,000 rubles, from the state federal budget.

As of January 1st, 2014 23,067 live calves were born in the Krai reindeer farms and 12,047 reindeer died, that is, $12.2 \%$ of the entire herd, as per issue 25 of the annual agriculture report, The State of Reindeer Husbandry. The female to male ratio is $3: 1$. Neutered males make up $24.7 \%$ of the herd, that is, 24,427 reindeer.

Reindeer farms (apart from Surdinskoye) have ceased stock breeding activity, which may result in the loss of certain breed characteristics and issues with breeding the desired type of reindeer. The unbalanced gender and age herd composition makes it impossible to guarantee a high and stable output performance and efficient use of reindeer pastures.

Reindeer pastures are classified under various land categories and are accounted for as woodlands, tree, shrub and bog lands, disturbed, and other lands. Agricultural lands suitable for reindeer husbandry make up $26,268,600$ hectares. Also, $24,903,500$ hectares of national forest are used as reindeer pastures within the Taymyr Dolgano-Nenets and the Evenk Municipal Districts. The total area of reindeer breeding-friendly pastures has decreased, as the pastures vacated when reducing domesticated herds are now occupied by wild reindeer.

The most worrying thing is the increase in reindeer population on the left bank of the Yenisei River. Data provided by farms suggests that 84,910 reindeer graze on a territory of 2,601,400 hectares (as per the Reindeer Farmland Register), that is, there is an average of 30.6 hectares of land per reindeer, whereas the recommended area per reindeer is 80 to 100 hectares on average. Data on the feeding capacity of pastures belonging to reindeer farms is out of date; nowadays the state land management database does not have any up-to-date geobotanical maps.

Epizootic diseases remain a big issue too. The northern part of the Krai is a high-risk area for natural focal diseases, such as anthrax, rabies, tularemia, and brucellosis. According to official stats, nowadays the Taymyr DolganoNenets Municipal District includes 39 currently registered areas with past outbreaks of anthrax. These territories cover a total area of over 4,500 km². A hantavirus of tick-borne viral encephalitis was recorded in 1992 and named Taymyrsky.

Reindeer husbandry development in Krasnoyarsk Krai is hampered by poor facilities and issues with processing quality, preservation, and guaranteed and uninterrupted product sales.

\subsection{Dolgan reindeer herding}

In November 2014 researchers from the Siberian Federal University and Astafyev Krasnoyarsk State Pedagogical University went on an expedition to the Taymyr Municipal District within Krasnoyarsk Krai (settlements of Khatanga, Zhdanikha, and Kresty). Presented below are the results of their expert interviews with executive authorities on the current and future development of reindeer husbandry with Dolgan people living on the Taymyr Peninsula. The Dolgans are currently the majority ethnic group in the area: counting over 1,000 people, they are present in all the northern settlements. The Nganasans make up about 60 people and their distribution throughout the settlements is uneven, which is why their culture is gradually dying out. At the moment, northern (Zhdanikha, Novorybnoye, Syndassko, Popigai) and southern (Kresty, Novaya, Kheta, Kataryk) settlements offer substantially different lifestyles. People living in the northern settlements maintain their traditional trades, such as hunting and fishing. There are hunting areas; generation after generation live in tundra shacks ("baloks"); and children pick up reindeer herding knowledge and skills from their parents, as long as there are wild reindeer in the area. Cultural practices of the southern settlements primarily focus on national traditional food. Here, reindeer herding is no longer the key economic activity due to lack of wild or domesticated reindeer in the area.

Solving a number of current issues could help keep Taymyr as a home for indigenous peoples. Issue One: traditional reindeer herding is abandoned as a lifestyle. The reason is that children are taken out of their family environment to attend a local school; later, as young adults, they choose to keep up with modern civilization. Issue Two: the nomadic tradition is gone and the nomadic tundra routes are lost. Southern settlements have lost their connection with the reindeer. Younger generations no longer aim to adopt the knowledge and experience required for practicing a trade in the tundra. Issue Three: tribal communities as family clusters and legal persons are gone; individualism is gaining 
momentum in both lifestyle and money-making. Issue Four: lack of reindeer makes it impossible to properly maintain a family in the tundra; due to a limited number of public sector jobs (at nurseries, schools, clubs, community centers, and town halls), settlements fail to provide close-to-home jobs for all their residents. Nomad benefits of 4,000 rubles remain the only source of income for most of the population. Traditional nature management is the one and only form of maintaining Northern indigenous practices and culture. Should this area be certified, it could open up the door to international markets. There is also hope that a certified status would give indigenous peoples a priority right to use their native lands which have been home to multiple Northern generations. Native people want to be sure their voices are heard when life-changing decisions are made in the North and hope their interests are taken into account, should large companies come to the area. There is an opinion that local culture can be preserved only if reindeer herding is developed in the North. This would make people want to live in the tundra, keep their national homeware in their shacks, live with their families in their nomadic tents ("chums"), make traditional clothing, speak their native language, sing their traditional songs, and so on. At the moment, the Dolgan culture is preserved in songs, embroidery, and bead weaving. There are bone carvers, a bone carving workshop (carvings are made out of mammoth tusks and reindeer antlers), and original artists. The problem is, there are no students willing to take over the experience. There is not a single craftswoman who could properly make a traditional parka or a pair of Dolgan boots. Ornaments have lost their meaning: they are pretty much all stylized now.

These days the quality of life in different settlements varies in terms of their ethnic composition and ways of preserving their language and culture. Many indigenous Northerners were born and grew up in the tundra; many of them have relatives who hardly visit any settlements; and there are some who received education in a settlement and went back to help their families. Most natives live on nomad benefits which are insufficient for a family with three or more children. The lack of domesticated reindeer all over the northern area and wild deer in the southern territories make it important to conduct research into ways of preserving the unique indigenous practices and creating work places, both in the tundra and in standalone settlements. Should traditional nature management areas be created, the following criteria can be applied to see whether they are beneficial to the indigenous peoples. 1. The general standard of living (since it is hard to preserve one's language and culture when struggling to survive). This is a complex criterion because it is related to a traditional nature management area (including its level of economic prosperity), local unique artists' (such as embroiderers or bone carvers) involvement in the Krai's cultural life and their level of participation in exhibitions and other public events. Only by looking at the economy and culture in combination, can one have a proper understanding of how well a traditional nature management area is developing. 2. The level of employment: under the current circumstances, it is not feasible to have everyone involved in reindeer herding (due to lack of domesticated reindeer and low nomad benefits). It is necessary to study the job market for Northern indigenous minorities. At the moment, boosting business requires substantial legal and financial backing from the government in terms of setting up transportation links and sales markets. 3. How many people stay in traditional nature management areas and for how long: the number of people living in shacks, staying in the tundra, and so on needs to grow. If there are people coming into the area, a new culture will be able to unfold. 4. The revival of reindeer herding as a lifestyle: this is the very thing that binds together all the elements of the Northern indigenous minorities' culture, allowing communities to be created and generations to keep living in the tundra. This can also enable a large number of support programs (such as official employment provided one has reindeer herding experience).

\subsection{Nenets reindeer herding}

Research into the state of reindeer herding in the Nenets community was conducted in the summer 2011 and fall 2013. The 2011 expedition visited the settlement of Nosok where researchers were able to familiarize themselves with the reindeer herders' everyday life and traditions. Nosok is a settlement $221 \mathrm{~km}$ to the north of Dudinka. As of 2011, the population of Nosok was 1,814 people, 1,554 of them belonging to Northern indigenous minorities $(85.7 \%$ of the total population); with 1,163 people (64.1\%) living a nomadic lifestyle. Nosok can be classified as a multinational settlement: as of 2010, the Nenets made up $82.6 \%$ of its total population. The 2013 expedition took place in Dudinka, which is where most of the Taymyr Municipal District authorities are based, including those in charge of reindeer herding development.

\subsubsection{Reindeer herding as a branch of the Nenets economy}

Nenets reindeer husbandry became seen as a branch of the economy only in the USSR times. Nosok has a long history of reindeer herding. Once the Soviets came to power, basic manufacturing associations started to appear in Taymyr and soon after, cooperative associations ("artels") and collective farms ("kolkhozy"), which expanded into state farms 
("sovkhozy"). The first agricultural associations to appear in the settlement in the 1940's were the artels Novy Put ("New Path") and Zarya ("Dawn") which specialized in domestic venison production and preparation, fishing, and peltryware. In the late 1950's Zarya was named one of the best associations in the area. In 1960 Zarya merged with an agricultural artel, Krasny Taymyrets ("Red Taymyr Dweller"), and subsequently renamed Zarya Taymyra ("Dawn of Taymyr").

In the early 1960's Zarya Taymyra was the area's top collective farm by all measures. It merged with another collective farm, Gvardeets ("Guardsman"), and in 1975 was upgraded to a state farm. Another increase in economic activity happened between 1981 and 1986. In 1982 the settlement was praised as "exemplary" and in 1983 successful operation earned it a District/Okrug/Krai Challenge Red Banner; for the first time in Taymyr's history a state farm received a Central Committee of the USSR Communist Party banner and a 5,000-ruble reward.

As the whole country was going through a tough period from 1993 to 2002, government subsidies dried up and in 2003 Zarya Taymyra was liquidated and its reindeer herd became municipal property. It is currently being rented privately. "Reindeer herding is gradually improving in Taymyr. It is run by the private sector rather than the state. Herders own their reindeer. It used to be that reindeer herding was all over Taymyr, in all its districts, but nowadays it remains mainly with Nenets people in the Ust-Yeniseysk District. The Nganasans used to be reindeer herders, but they no longer do any herding: their trade is gone now," says a Nenets education worker from Dudinka.

Nowadays reindeer herding is a subsidized branch of agriculture. In this day and age, reindeer are bred not only and not so much for the community's needs as used to be the case in the Pre-Soviet era, but for sale as in the Soviet times. Hence the key issue: the downfall of collective and state farms went hand-in-hand with the collapse of a fine-tuned sales and processing mechanism for reindeer products. Both herders and agricultural authorities admit that sales markets are very poorly developed. A local government worker for reindeer herding as a branch of agriculture even insists that reindeer herding is one activity, whereas processing and sales are another and they are "different things". One expects them to be links in the same chain though.

There is some reindeer product processing, but its scale is nowhere near sufficient. There are venison processing facilities operating in Norilsk. A Dudinka-based company, Severnaya Gavan ("Northern Harbor"), is just getting into venison processing, but its main focus is fish products. Shops selling venison can be found in Krasnoyarsk and Norilsk. Not a single company trades velvet antlers or reindeer skin on a large scale. The skin is mostly used to make arts and crafts, footwear, and occasionally clothing. But this is still a marginal fraction of the total number of hides taken from the butchered reindeer.

Inextricably connected with reindeer herding is the issue of the environment, that is, pasture quality and free-range facilities. There is a gas pipeline going through Northern Siberia, and it affects animal migration routes. Of course, there are places where the pipe was lifted up two or three meters so that reindeer could walk under it, but, quoting locals, you cannot explain to a reindeer that there is a pipe lifted especially for him. In winter, when the pipe is covered in snow, a herd is more or less able to cross it over, but for the most part reindeer migration happens in the fall. Nenets people complain that most pastures have been ruined: criss-crossed by machinery or contaminated with heavy metals and other poisons. "The environmental situation varies from place to place. Because of Nornickel, Lake Khantayskoye is a disaster. It is contaminated with heavy metals and waste. And some areas are harmed by locals themselves who turn their environment into a dump," says V. H. Vengo, Northern Indigenous Minorities Advisor to the Head of the Taymyr DolganoNenets Municipal District.

Some estimates suggest that environmental deterioration alone will obliterate reindeer farming within a few decades. "Industrialists drive indigenous peoples out of their native lands. This used to be and still is the case. And it will be the case until this issue is tackled at the state level. Should the North continue to be developed at the same pace, there will be no reindeer herding in 50 years' time. Or, perhaps, some gaunt traces of it will remain. The tundra is already all criss-crossed by all-terrain vehicles, but reindeer moss won't grow again once an ATV has gone over it. It will be a disaster," says S. G. Burelomova, Head of Department for Taymyr Indigenous Minorities Lifestyle and Natural Habitat Protection.

Experts believe that, should reindeer herding disappear as a traditional trade practiced by indigenous peoples, it will still remain in another form: as a profession. "Of course, reindeer will remain. This will go the same way as in Finland where they drive cars and collect bags of reindeer moss, like cow food. The reindeer will remain, but the traditional lifestyle will not. Reindeer herding will become a profession. Anyone will be able to become a reindeer herder," says respondent S. Burelomova.

The Nenets believe the following steps must be taken to put reindeer herding right: 1) increase state subsidies; 2) tackle the environmental issues related to pastures; 3) probably conduct some selection work; 4) set up sales markets for reindeer products.

Summing up this overview of Nenets reindeer herding as a branch of the economy, one can say that it is less than 
just inefficient: it does not even pay for itself. Product processing and sales are poorly developed. Nenets reindeer herding pretty much survives on state subsidies. Nevertheless, the Nenets continue to develop their reindeer husbandry and the livestock is gradually growing. As a result, it makes sense to view Nenets reindeer husbandry as a symbolic activity rather than a business. Taymyr reindeer herding is a symbolic way of maintaining one's regional and ethnic identities.

\subsubsection{Reindeer herding as a key ethnic identification factor for the Nenets}

Experts and respondents alike share an opinion that reindeer livestock size is the main indicator of how well off a Nenets person is. "The key thing is the number of reindeer. The more reindeer people have, the better off they are. The more reindeer, the bigger the fortune", says S. G. Burelomova. "Indigenous communities rate a person's standard of living by the size of their reindeer livestock: under 100 animals is a so-so average; over 100-300 is OK, and 1,000 and over is well off", says D. B. Yaptune, a leading expert from the Agriculture and Traditional Trades Department. Interviewers also point out that in the tundra, a reindeer provides everything for a man and entirely determines the life of a tundra dweller: herder families follow their reindeer and move from place to place every one to three days. "A reindeer provides you with everything in the tundra: your house, your clothing, and your food - it gives you everything. Reindeer herders sell the carcasses and use the hide to make clothing. And it's there in their everyday lives: covering their tents and proving their clothing," says A. I. Porotova, head of the Masterskaya Mukustur ("The Mukustur Workshop") farm.

Nenets respondents spoke about their unique ethnic group, assimilation and how it may affect their community's future. When speaking about their ethnic-specific characteristics, they name reindeer herding, freedom (regular migration following reindeer independent of any authorities; the endless tundra which makes it challenging to move to a city with its limited spaces), a special psychology (helping them overcome the hardships and extreme living conditions of the North), a warm heart, and openness (as opposed to the calculating and pragmatic market society).

Most Nenets respondents spoke about a gradual disappearance of their ethnic language. At the same time, their responses suggest that the language is preserved among those who maintain a traditional lifestyle, that is, herd reindeer (or, to a lesser extent, hunt and fish). Respondent $\mathrm{V}$. H. Vengo says, "As long as there is language, there is a people, but to keep the language going, one has to keep up the traditional activities, that is, reindeer herding, hunting, and fishing. And reindeer herding is the top priority because the Nenets culture is all centered around the reindeer and the tradition of growing, using, and breeding the domesticated reindeer. This is why all our fairy-tales and all our calendars are about the reindeer." A good chunk of the Nenets vocabulary is connected with reindeer herding. Hence, should reindeer herding become extinct, not only a fairly important part of the vocabulary will fall out of use, but also the very existence of the language will be threatened, as is currently the case with the Nganasan language.

Reindeer husbandry does more than just accompany a Nenets person at all times of their life, allowing them to keep their ethnic language going and acting as a life-orienting factor, it also helps systematize their idea of the afterworld. For example, if you visit the Nosok cemetery, you will find adult people's possessions, such as furniture and kitchen utensils, placed next to their graves. Some graves have reindeer sleigh ("narty") and goads ("khorey") because the tradition is, when a herder dies, a reindeer must be killed so that the herder has something to ride. Reindeer meat is carefully removed from the bones and given out to those who assisted with the funeral arrangements. An entire bare reindeer carcass, including antlers, is left at the cemetery.

The symbolic nature of reindeer herding as one of the key ethnic identification factors for the Nenets and the Dolgans is most vividly expressed in visual ethnic arts.

\subsection{The reindeer visual image in Nenets and Dolgan arts}

This study is based on the analysis of paintings, drawings, and bone carvings made by Dolgan and Nenets artists. The visual image of a reindeer is present in works by Nenets artists I. K. Vylka and L. A. Lar, Dolgan artist B. N. Molchanov, and bone carver V. S. Kirgizov. By analyzing works featuring reindeer, we were able to group them into two categories: 1 ) artwork using the reindeer image as a guide, chaperone or spirit medium. Such characteristics are expressed from two perspectives. On the one hand, a reindeer acts as a man's guide through daily life; and on the other hand, as a guide in a religious or mythological sense. 2) genre-specific landscape artwork.

The first group includes artwork featuring scenes from a reindeer herder's life. The most frequent subject matters are going hunting and returning home. Representative of this category are bone carvings by V. S. Kirgizov, such as After the Bride (mammoth tusk, metal), Into the Tundra (mammoth tusk, stone), Astride a Reindeer (mammoth tusk, amber), Hunting Time (mammoth tusk, amber, reindeer antler), On the Way Home (mammoth tusk), Little Reindeer Herder 
(mammoth tusk, mammoth rib); paintings by B. N. Molchanov, such as A Sleigh Caravan (1989), A Sleigh Caravan in the Mountains (1989), and others. Most of the time, the character's personality is unspecific. It is rather a generalized ethnic image of a man wearing his national winter clothing. Any identifying details are omitted. The only item accompanying the character is his weapon which identifies him as a reindeer herder, a generalized representative of the herder community. Most often, a reindeer herder is depicted astride a reindeer. This kind of composition visually creates vertical and horizontal adjoining lines that deliver a sense of balance, stability, and overall compositional unity. A man and his reindeer meet in a halfway world and become alike.

The reindeer image in a religious/mythological context can be found in painting by L. A. Lar, such as The Climb, Out for a Visit (2001), The Long-Awaited Guest (2001), Num's Eyes (1992), and bone carvings by V. S. Kirgizov, such as The Wild One (mammoth tusk, stone), Motherhood (mammoth tusk), Shamanic Ritual (mammoth tusk), and others.

Num's Eyes (1992) by L. A. Lar depicts a shaman tapping his drum in the foreground and Num's Eyes looking ahead, in the background. What links the characters in their dialogue is the shaman's most vital accessory, the drum ("penzer"), a musical instrument which brings together a number of symbolic concepts reflecting the complexity of the Nenets' and the Dolgans' religious beliefs. The key concept comes from the drum itself. The drum symbolizes a reindeer that the shaman rides on land, up into the sky or down into the underworld. The reindeer is a mediator between the man's world and the gods.

The idea of blessing the reindeer with religious powers can also be traced in bone carving. Small size, generalized features, snow-white figures, and the Nenets' and the Dolgans' religious worldview (worshiping the reindeer as their sacred ancestor, patron, and Nature's perfect creation) make images of the reindeer feel like religious artwork. Of special importance are reindeer antlers. Following the Nenets' idea of afterlife, reindeer antlers are traditionally left at the herder's burial place so that he could continue herding in another world (see Antlers on the Hill, The Sacred Place (2007), The Place of Sacrifice, and other works by L. A. Lar).

Genre-specific landscape paintings are represented in works by B. N. Molchanov: The Reindeer Run (1983), In the Avam Tundra (1986), A Sleigh Caravan in the Mountains (1989), The Putoranas in Spring (1991), Spring in the Putoranas (1992), Treading the First Snow, and Reindeer Running. Walking or running reindeer are among the key motifs. These motifs unfold in the Nature, which is traditionally viewed by the Nenets and the Dolgans as the Mother of all living beings. The reindeer typically cover only a small part of the canvas. Similar color schemes used for the natural environment and the reindeer combined with a soft contour create an image where the characters appear at one with Nature. It is as if the reindeer were part of the source of Nature. It is not coincidental that the reindeer often move towards the center of the image. The signs and symbols used in the artwork carry the idea of unity in Nature where all living beings become its integral and, at the same time, dependent part.

\section{Concluding Remarks}

Dolgan reindeer herding is almost gone; its decline caused an economic downfall and disrupted the traditional lifestyle with its traditional activities. Nowadays, the Dolgan culture survives primarily in its nomadic form as living conditions in the tundra enable tribal communities to engage in their traditional trade. Those who live in settlements manage to survive only by running small businesses and working for the state social services. In this case, reindeer herding bears a symbolic nature and acts as a binding factor for the ethnic group. Without a sales market, transportation links, and a proper financial backing from the government, it is impossible to improve people's standard of living in a tangible way.

Nenets reindeer herding is an economically inefficient subsidized branch of Northern agriculture. But it keeps going nonetheless and there are even signs that the number of reindeer is growing. This suggests that reindeer herding plays a symbolic rather than economic role. Nenets reindeer herding is an ethnicity-forming and ethnicity-sustaining factor. Its presence ensures that the indigenous Nenets culture can maintain its language, traditional cuisine, clothing, rituals, household items, and other integral elements.

Today's regional identity practices are also ethnic. The economy is undergoing a transformation: people no longer make and distribute goods and services, but rather the signs, symbols, and images expressed in indigenous peoples' visual artwork. A distinguishing feature of the Nenets' and the Dolgans' visual artwork is that it represents the signs and symbols associated with the primeval, traditional ethnic and cultural values which are partly lost in this day and age. As an example, the following primeval ethnic and cultural values are used by artists: the man and the reindeer coexisting in harmony, a special religious status assigned to the reindeer, a single ethnic and cultural worldview foundation, including the image of unity between all living beings and Eternal Nature. 


\section{References}

Alia, V. (2010). The new media nation: Indigenous peoples and global communication (Vol. 2). Berghahn Books.

Bakhova, N., Pimenova, N., Koptseva, N., Luzan, V., Semenova, A., \& Sertakova, E. (2012). Ethno-Formative Mechanisms and Forms of Self-Awareness of Indigenous Peoples Under Conditions of External Civilization Pressure (by an Example of the Yakut Ethnic Group). Journal of Siberian Federal University. Humanities and Social Sciences, 7 (5), 988-1004.

Batashev, M. (2013). Ethnic History of Indigenous Peoples of the Yeniseysky Uyezd in the 17th Century and Their Fortunes. Journal of Siberian Federal University. Humanities and Social Sciences, 6 (6), 842-869.

Bostedt, G., \& Lundgren, T. (2010). Accounting for cultural heritage - A theoretical and empirical exploration with focus on Swedish reinreindeer husbandry. Ecological Economics, 69(3), 651-657.

Chard, C. S. (1963). The Nganasan: wild reinreindeer hunters of the Taimyr Peninsula. Arctic Anthropology, 1(2), 105-121.

Ehrich, D., Ims, R. A., Yoccoz, N. G., Lecomte, N., Killengreen, S. T., Fuglei, E., \& Sokolov, V. A. (2015). What can stable isotope analysis of top predator tissues contribute to monitoring of tundra ecosystems? Ecosystems, 1-13.

Karlova, O., Koptseva, N., Kirko, V., Reznikova, K., Zamaraeva, J., Sertakova, E., Kistova, A., Semenova, A., Shishatsky, N., Nevzorov, V., Ilbeykina, M., \& Pimenova, N. (2013). New Future of Siberia. Krasnoyarsk: Siberian Federal University. [in Russian]

Kim, U. E., \& Berry, J. W. (1993). Indigenous psychologies: Research and experience in cultural context. Sage Publications, Inc.

Klein, D. R., \& Kuzyakin, V. (1982). Distribution and status of wild reinreindeer in the Soviet Union. The Journal of Wildlife Management, $728-733$.

Klokov, K. B. (2011). National Fluctuations and Regional Variation in Domesticated Reinreindeer Numbers in the Russian North: Possible Explanations. Sibirica, 10(1), 23-47.

Koptseva, N. (2014). Indigenous peoples of Northen Siberia: current problems. AYER, 1, 55-74.

Koptseva, N., \& Kirko, V. (2014a). The information basis for formation of positive ethnic identities in the process of acculturation of indigenous peoples of the Arctic Siberia (Krasnoyarsk, Russia). Life Sci J, 11(8), 479-483.

Koptseva, N., \& Kirko, V. (2014b). Modern specificity of legal regulation of Cultural Development of the Indigenous Peoples of the Arctic Siberia under the global transformations. Life Sci J, 11(9), 314-319.

Koptseva, N., \& Kirko, V. (2014c). Post-Soviet practice of preserving ethnocultural identity of indigenous peoples of the North and Siberia in Krasnoyarsk Region of the Russian Federation. Life Sci J, 11(7), 180-185.

Krivonogov, V. P. (2013). The Dolgans' Ethnic Identity and Language Processes. Journal of Siberian Federal University. Humanities and Social Sciences, 6(6), 870-881.

Krupnik, I. (2000). Reinreindeer pastoralism in modern Siberia: research and survival during the time of crash. Polar Research, 19(1), 49-56.

Laruelle, M. (2013). Russia's Arctic strategies and the future of the Far North.ME Sharpe.

Libakova, N., Sitnikova, A., Sertakova, E., Kolesnik M., \& Ilbeykina M. (2014). Interaction of the Yakut ethnicity and biological systems in the territory of the Sakha Republic (Hordogoy settlement, Suntarsky District) and Krasnoyarsk Krai (Essey settlement, Evenks District). Life Sci J, 11(6s), 585-592.

Luzan, V. (2014). On the Problem of Conceptual Grounds of Cultural Policy. NB: Issues of Society and Politics, 10, 135-158.

Makarov, N. (2013). The Ancient Stages of the Culture Genesis of the Krasnoyarsk Northern Indigenous Peoples. Journal of Siberian Federal University. Humanities and Social Sciences, 6(6), 816-841.

Næss, M. W., Bårdsen, B. J., Pedersen, E., \& Tveraa, T. (2011). Pastoral herding strategies and governmental management objectives: predation compensation as a risk buffering strategy in the Saami reinreindeer husbandry. Human Ecology, 39(4), 489-508.

Newcity, M. (2009).Protecting the Traditional Knowledge and Cultural Expressions of Russia's Numerically-Small Indigenous Peoples: What Has Been Done, What Remains to Be Done. Texas Wesleyan Law Review, 15, 357-414.

Pape, R., \& Löffler, J. (2012). Climate change, land use conflicts, predation and ecological degradation as challenges for reinreindeer husbandry in northern Europe: what do we really know after half a century of research? Ambio, 41(5), 421-434.

Phinney, J. S. (1989). Stages of ethnic identity development in minority group adolescents. The Journal of Early Adolescence, 9(1-2), 34-49.

Pimenova, N. (2015). Indigenous peoples in the current situation: the scope and content of the concept. Sociodynamics, 1, 112-134.

Reznikova, K. (2013). Preservation and Transformation of Certain Aspects of the Traditional Way of Life of the Indigenous and SmallNumbered Peoples of the North, Living in the Settlements (Posyolki) of Turukhansk and Farkovo. Journal of Siberian Federal University. Humanities and Social Sciences, 6(6), 925-939.

Rowe, S., Baldry, E., \& Earles, W. (2015). Decolonising Social Work Research: Learning from Critical Indigenous Approaches. Australian Social Work (Forthcoming).

Seredkina, N. (2014). Revisiting Methodological Principles of Cultural-Semiotic Approach in Studying Art of Indigenous Peoples of the North, Siberia and the Far East. Journal of Siberian Federal University. Humanities and Social Sciences, 8 (7), 1342-1357.

Sitnikova, A. (2015). On the Problem of Research Methodology of Culture as a Socio-Anthropological System. Sociodynamics, 1, 75-100.

Steinhauer, E. (2002). Thoughts on an Indigenous Research Methodology. Canadian Journal of Native Education, 26(2), 69-81.

Syroechkovskili, E. E. (1995). Wild reinreindeer. Science Pub Inc.

Syrovatsky, D.I., \& Vinokurov, V.S. (2012). Olenevodstvo kak otrasl ghizneobespecheniya na Severe \{Reinreindeer herding livelihood as a branch of the North]. Problems of Modern Economics, 4, 501-502.

Tichotsky, J. (2014). Russia's diamond colony: the Republic of Sakha. Routledge.

Wheeler, S. (2011). The magnetic north: notes from the Arctic Circle. Macmillan.

Williams, T. M., \& Heard, D. C. (1986). World status of wild Rangifer tarandus populations. Rangifer, 6(2), 19-28.

Ziker, J. (2014). Sharing, Subsistence, and Social Norms in Northern Siberia. Experimenting with Social Norms: Fairness and Punishment in Cross-Cultural Perspective, 337. 